\title{
Criminologie
}

\section{Résumé du contenu/English Summary}

\section{Dorothy Crelinsten}

Volume 15, numéro 2, 1982

Criminels et psychiatrie

URI : https://id.erudit.org/iderudit/017167ar

DOI : https://doi.org/10.7202/017167ar

Aller au sommaire du numéro

Éditeur(s)

Les Presses de l'Université de Montréal

ISSN

0316-0041 (imprimé)

1492-1367 (numérique)

Découvrir la revue

Citer ce document

Crelinsten, D. (1982). Résumé du contenu/English Summary. Criminologie, 15(2), 135-137. https://doi.org/10.7202/017167ar d'utilisation que vous pouvez consulter en ligne.

https://apropos.erudit.org/fr/usagers/politique-dutilisation/ 
For the first time, in this issue, our review deals with the subject of clinical criminology. In order to furnish criminologists and practitioners with the experiences and evaluations of a discipline that stems more or less from psychiatry and psychology, we asked doctors from the Institute Philippe Pinel for their collaboration. They agreed to write some articles for this issue which, in our opinion, have the great merit of showing the theoretical and empiric difficulties created by the everlasting discussion of whether the criminal who is mentally ill should be sacrificed to the objective of protecting the community, or should society, through its laws, be seen to condemn, a priori, the right to be different.

We do not intend to go into the debate here, or to take a stand on the issue, but only to give our readers some food for thought, based not only on an ideological approach, but also, and above all, on the realities lived from day to day by those who have the responsibility of treating, of "curing" and of facilitating the reintegration in society of people whom public opinjon and the press reject as some sort of monsters.

Dr. Lionel Beliveau, director of this hospital, which is in itself a unique experience, writes that: In the public mind, institutions like the Philippe Pinel Institute of Montreal have always been perceived as taking calculated risks with the public safety in order to rehabilitate the persons entrusted to their care for treatment. It might be well to remember that if the primary objects of an institution like the Institut Philippe Pinel of Montreal is to treat and rehabilitate people, ... this interest is not contrary to the public interest or public safety, as some would have us believe.

Jean Poupart, Michèle Lalonde and Jean Dozois, criminologists, do a critique of the assessment of dangerousness, while doctors, such as Pierre Laberge, Jocelyn Aubut and Bruno Gravier, rea- $*$. dily speak of the anguish and tensions of their patients. They all agree on the essential need to improve evaluation methods, to make an in-depth study of the socio-cultural characteristics of patients and to take into account not only their present, but their past situation as well. With the help of studies of this kind, who do we find?

\footnotetext{
* Translator of the International Centre for Comparative Criminology.
} 
People rejected by their families from earliest childhood, people left to themselves, people for whom their is neither a place in society or $x$ any chance for growth; poor people, with little schooling, unprepared for the labour market, and not knowing how to cope. They are unable to face life and even less overcome the fantasies that caused them to commit acts which, of little importance at first, become more and more serious, even to the point of murder.

They are a difficult clientele for the clinician, for there are enormous differences between the case of matricide cited by Doctor Laberge and sexual delinquents, for example, who are perforce a much greater threat to the community since they are less selective. The article contributed by Doctor Gravier and André Surprenant points out the difficulties this presents for the institution, not only from the point of view of treatment, but of its evaluation with regard to the release of the patient. Sheilagh Hodgins adds a more criminological element, presenting the objectives and research methods now in progress, or that should be undertaken, at the Institut Philippe Pinel.

In the article written with the collaboration of doctors, psychologists and criminologists and which is signed by Doctor Lionel Beliveau, Jacques Hebert, Yvon Lefebvre and Sheilagh Hodgins, there are some partial answers to several questions, both theoretical and empiric. They describe the law, the judicial procedures and the past and present of those who have been subjected to them; in other words, case histories. In addition, based on an analysis of several studies, they show how difficult it is to rely on the results obtained in this way because of the quality of the samples, which are too small, too limited and incomplete in matters as important as the social, educational and culturel background, and sometimes even the medical history, of those concerned. Thus they increase the doubt, which we share, about such complex situations as those experienced by mentally ill criminals within a system of justice that does not allow for the "right to be different"; it is primarily concerned with the proof of guilt, since this is its role in the application of a justice that doubtless would be, but is not necessarily, fair.

As we have already said, it is not our intention to go into the subject, but merely to promote some thought about the treatment of mentally ill criminals in Quebec and elsewhere in Canada. This is one of the reasons we add an analysis of 3 books recently published and reviewed by Pierre Lagier, André Normandeau and Alice Pari- 
zeau. The bibliographical analysis by Jacqueline De Plaen, as well as those at the end of each article, will permit our readers to further their knowledge, if they wish, based on the work done in other contexts, geographical and cultural.

Both medically and socially, there are still many grey areas in our perception of these individuals, the disinherited of our society, these mentally ill who are not fit for trial, according to the law, but whose acts condemn them, ipso facto, to more or less long periods of isolation in our institutions. Then at last, when the day comes for their release, they return to the community, only to end up, in most cases, serving time in a penitentiary.

This is the tragic and inevitable fate that is imposed on individuals in the name of protection of society, no doubt because of the lack of other solutions and other methods of treatment, constantly sought from one generation to another and from one society to another. 